\title{
The telephonist and the service quality gap
}

\author{
Jay Owens* and Terese Loggenberg \\ Graduate School of Business Administration, University of the Witwatersrand, 1 Jan Smuts Avenue, P.O. Wits 2050, \\ Republic of South Africa
}

Received 2 April 1992, accepted 31 August 1992

\begin{abstract}
With this research customer perceptions and expectations of the in-house telephone service were investigated in four service organizations. Service quality was measured by means of a multiple item scale for measuring customer perceptions. The findings were supported by inputs from the managers and telephonists of these firms. The results showed that overall the quality of the service, provided by the in-house telephone service in the companies investigated, lagged behind customer expectations. The indicators for the gaps on the conceptual service quality model correlated well with the overall quality scores. Recommendations are made that the managements of service firms should include the telephonists in their overall service quality management, and provide more training on communications skills on service and customer orientation for the telephonists. Telephonists should also receive more support from management and staff since they feel left out of the organization. The regular measurement and monitoring of service quality should also include this very important function as first contact with any service company.
\end{abstract}

Met hierdie navorsing word kliënte se persepsies en hul verwagtinge van die binneshuise telefoondiens in vier diensorganisasies ondersoek. Diensgehalte is deur middel van 'n veelvoudige item-vraeboog bepaal wat kliëntepersepsies meet. Die bevindinge is ondersteun deur insette vanaf die bestuurders en die telefoniste van die bogenoemde firmas. Die bevindinge dui daarop dat die algehele gehalte van die diens wat deur die binneshuise telefoondiens aangebied word, nie aan kliënteverwagtinge voldoen nie. Die gapings van die diensgehalte-model, korreleer goed met die algehele dienstellings. Aanbevelings word gemaak dat die bestuur van die firmas die telefoniste behoort in te sluit in hul algehele diensgehaltebestuur, en dat meer opleiding in kommunikasiekundigheid, in diens, en opleiding in kliëntegerigtheid vir telefoniste aangebied behoort te word. Telefoniste behoort meer ondersteuning van beide bestuur en personeel te ontvang, aangesien hulle voel dat hulle nie altyd deel van die organisasie is nie. Die gereëlde bepaling en waarneming van diensgehalte behoort ook hierdie baie belangrike funksie, as eerste kontak met enige diensmaatskappy, in te sluit.

*To whom correspondence should be directed.

\section{Introduction and problem definition}

New pauterns of commerce, trade and government have been built on the telephone network system. Indeed, innovative services such as tele-marketing have successfully positioned themselves in the market-place to capitalize on the extensiveness of the telephone network and the convenience of conducting business by telephone (De Sola Pool, 1977 and Keller, 1977). Counselling services, couriers, hotels and hospitals, are examples of services which are heavily dependent on the telephone system for operating their business.

The increased use and reliance on the telephone implies an increased emphasis on the 'first contact' person for the business, namely the telephonist. Intensifying competition and deregulation in the services sector have led many service businesses to seek profitable ways to differentiate themselves. One strategy that has been related to success in their businesses is the delivery of high quality service (Thompson, De Souza \& Gale, 1985).

To compound the problem further, expectations of customers have increased over the past decade. This may be due to increased competition in the services sector, and/or the fact that the norms and expectations for service quality excellence have become more stringent.

'There

service encounter. Consequently, if money, time and attention are to be spent on improving the experience of service, then the largest payoff may well occur in the early stages of the service encounter' (Maister, 1985). This may well be at the first point of contact.
Despite the ubiquity and centrality of the telephone, very few service organizations appear to recognise the important marketing role played by this function, either in terms of the training and employment practices provided for their telephonists or in monitoring their performance. Although it is generally accepted that the telephonist is perceived as the 'communications heart' of the organization, very little appears to be done to operationalize this concept.

The objective of this research was to test if a gap existed between customer expectations and customer perceptions of the telephonist function in four service organizations.

\section{Survey of the theoretical literature}

\section{Concept of service quality}

The quality of services, in contrast to that of goods, is an abstract and elusive construct. Because services are performances rather than products, precise and uniform quality specifications cannot be established. In most services, quality occurs during service delivery, usually in an interaction between customer and contact personnel of the organization and the deliverer of the service cannot be separated from the service itself. Hence the quality of the service provided is dependent on the performance of the service deliverer (the employees of a service company). The high degree of involvement of personnel in the production of a service introduces a degree of variability and inconsistency in the outcome that is not present in a mechanized process.

\section{Conceptualization of service quality}

Perceived quality refers to the consumer's judgement about 
the overall excellence or superiority of a product or service (Parasuraman et al., 1985; Zeithaml, 1986; Levitt, 1979). It is a form of attitude, related but not equal to satisfaction and it is the net result of a comparison of expectations with perceptions of performance.

A number of researchers (Jacoby \& Olson, 1985; Zeithaml, 1986; Gronroos, 1982) emphasize the difference between objective, mechanistic or technical quality, and humanistic, perceived quality. The mechanistic or technical quality refers to an objective aspect or feature of things or events; the humanistic quality refers to the subjective response of people to objects or events.

Olsavsky (1985) views quality as a form of overall evaluation of a produch similar in many ways to attitude. Holbrook \& Corfman (1985) concur, suggesting that quality acts as a relatively global value judgement. Exploratory research conducted by Parasuraman et al. (1985) supports the notion that service quality is an overall evaluation, or emotional response, similar to an attitude rather than a rational assessment of characteristics and attributes.

Oliver (1981) differentiates between satisfaction and attitude by saying that atittude is the consumer's relatively enduring affective orientation for a product, store or process, while satisfaction is the emotional reaction following a specific situation. This distinction between attitude and satisfaction is consistent with the views of Parasuraman et al. (1985), and Olsavsky's (1985) suggestion that service quality is a global judgement or attitude relating to the service.

Sasser, Olsen \& Wykoff (1978), Gronroos (1982), Parasuraman, Zeithaml \& Berry (1984) endorse the view that quality, as perceived by the customer, stems from a comparison between the expectations of the service they will receive, with their perception of the service which has in fact been delivered. Parasurman et al. (1985), conclude that if the perceived quality is less than the expected quality, a tendency toward totally unacceptable quality will occur with increased discrepancy between these two.

\section{Dimensions of service quality}

Parasuraman et al. (1985) found that irrespective of the type of service, consumers used similar criteria in evaluating service quality. The criteria fall into ten potentially overlapping dimensions, described as: tangibles, reliability, (performance consistency), responsiveness, communication, credibility, security, competence, courtesy, understanding and knowing the customer, and access. These ten dimensions were later refined and factor reduced to five, namely, reliability, responsiveness, assurance, tangibles and empathy (Parasuraman, 1988).

Other factors influencing or affecting the perception of service quality

Services are perceived to be inherently more risky than goods, but by developing an image of quality and professionalism, the service marketer can reduce the perception of risk for his service.

George \& Berry (198i) warn that any advertising campaign that leaves the impression that either functional or technical quality is better than it actually is, will only lead to an increase in expectations and expected service levels. The gap between expected and perceived service will widen even further, resulting in an increase in dissatisfaction and a deterioration of the corporate image. Similarly, Peters (1987) suggests that it is better for companies to under-promise and over-deliver than for them to make promises and not deliver.

Olsavsky (1985) and Holbrook \& Corfman (1985), view quality as a form of overall judgement or evaluation of a product, similar in many ways to attitude. If this is so, then all aspects and processes during the production of the service contribute to the overall service quality perception of the customer. Thus, the interaction of the telephonist with the customer makes them part of the service and therefore their attitude can affect the customer's view of the service provided.

\section{Managing service quality}

Because the service industry is becoming more and more competitive, the only means of differentiating a particular service from others is through managing the service quality in organizations. Albrecht \& Zemke (1985) referred to each interaction with the customer as a 'moment of truth', where each moment offers an opportunity to either enhance or detract from the customer's perception of the service. Since the telephonists interact with the customers continuously, it is important to monitor and manage their service quality.

Parasuraman et al. (1985) developed a service quality model indicating that the consumer's quality perceptions are influenced by a series of four distinct gaps occurring in organizations, namely: Gap 1, the difference between consumer expectations and management perceptions of consumer expectations, which is a function of marketing research orientation, upward communication and levels of management; Gap 2, the difference between management perceptions of consumer expectations and service quality specifications, which may be accounted for by management commitment, goal setting, task standardization and the perception of feasibility; Gap 3, the difference between service quality specifications and the service actually delivered, accounted for by teamwork, employee-job fit, technology-job fit, perceived control, supervisory control systems, role conflict and role ambiguity; Gap 4, the difference between service delivery and what is communicated about the service to the consumer, which is influenced by horizontal communication and the propensity to over promise; Gap 5 is the difference between expected service and perceived service. Service quality as perceived by the consumer depends on the size and direction of this difference, which in turn depends on the nature of the gaps associated with the design, marketing and delivery of services. Gap 5 is thus a function of Gaps 1, 2, 3 and 4.

\section{In-house telephone system as a service}

For the purposes of this research the in-house telephone system was analyzed as a service using the services marketing concepts in Lovelock's (1984) framework. According to this framework, the service operation system is perceived to be that area where the service is actually produced, and which may consist of an internal system not visible to the customer, as well as the contact person and physical support or environment which may be visible to the customer; the 
service delivery system is that area where the services are delivered to the respective customers, and may include the visible portion of the service operation system; the service marketing system encompasses both the service delivery system and that portion of the service operations system which is visible to the customer.

\section{Service concept}

The nature of the in-house telephone service is changing rapidly in response to technological advancements and companies are now able to install computerized telephone systems at affordable prices. Although the installation of such a system can drastically reduce the work-load placed on telephonists, it will not eliminate the need for at least one telephonist. Hence it enhances the technical quality of the service but does not necessarily improve the functional quality of the service. Furthermore, discussions in the subsequent focus groups indicated that the emphasis is shifting from the more mundane duties to an additional duty of providing a first-point-of-contact information service.

The in-house telephone service caters for the needs of two different market segments, namely, internal customers and external customers. It is important that the telephonists are aware and conscious of these expectations and, moreover, that they strive hard to satisfy the needs of both groups. It may therefore be concluded that the telephonist has an important role to play in managing the gap between a customer's prior expectations regarding the organization's service and his perceptions of the service after coming into contact with them. The contact time between the telephonist and the customer is often brief and it is therefore important to make the contact a positive experience, to ensure that the caller builds a positive image of the organization.

It can be concluded, therefore, that communications are key attributes in service delivery, that employees' indirect contact with customers require communication competencies, and that the management and marketing of the interface between employees and customers is an important services marketing task.

\section{Characteristics of the service}

The in-house telephone service has the following dominant characteristics: Intangible, invisible, perishable (the capacity of the telephone service cannot be stored), inseparable (the production of the telephonist's service cannot be separated from its consumption by the caller) and heterogeneity. These characteristics not only differentiate service production and marketing from goods production and marketing, but also create specific production and marketing problems.

Relationship between the in-house telephone service and the organization' sfunctional systems

If one analyses the telephone service itself in terms of the three interlocking systems as represented by Lovelock's (1984) model, one finds that the telephonist is involved in all three systems. Since the telephone is often the primary means of communication with external parties it is probably of more strategic value to the service delivery and marketing systems than to the operations system.

\section{Research methodology}

The research was conducted using the extended model of service quality, as developed by Zeithaml et al. (1988) as well as SERVQUAL, a multiple item scale for measuring customer perceptions developed by the same authors (Parasuraman, Zeithaml \& Berry, 1986). The methods and procedures used in the research were conducted using a similar research approach to that used by Zeithaml et al. (1988) to the extended model of service quality.

Focus group discussions were conducted with groups consisting of two training consultants, two customer liaison representatives from electronic switchboard suppliers, two telephonists and two managers. The purpose of the discussion was to gain insight into what were the key attributes of service quality with regard to the in-house telephone system of service organizations, and what problems and tasks were associated with providing a high quality service.

\section{Sample selection}

The sample for service organizations was selected on the basis of the extent of their reliance on the telephone in the performance of the service. In addition, an attempt was made to represent a cross section of services that vary along the key dimensions used by Lovelock to classify services (Lovelock, 1981).

In order to ensure confidentiality, the participating organizations were identified only by the service they provide, namely, a car rental organization, a courier service, an audit firm and a hotel.

\section{Sample selection: customers perceptions}

A list of twenty current customers was obtained from each company to test customer perceptions. The criteria for selection of the customers were that they should have used the company's services within the past three months, and that they be located in the PWV area.

\section{Sample selection: managers and telephonists}

The data obtained from managers and telephonists was used to assist in the analysis of the results, therefore small samples were used. Two senior managers from each of the participating companies were selected by the company to complete the questionnaire.

\section{Sample selection: customers expectations}

The expectations of the service by customers were tested using twenty randomly selected regular customers or telephone users from the four firms. Using the same method, the perceptions of the service by customers was tested on a similar sample of twenty customers. The assumption was made that expectations for telephonists service within the service industry would not vary much. The assumption was based on the research of Parasuraman et al. (1985) which found that irrespective of the type of service, consumers used similar criteria in evaluating service quality.

\section{Development of the questionnaires}

The focus group discussions generated a number of values which appeared to influence the perceptions of quality and, 
when summarized, resembled those developed by Parasuraman et al. (1985).

\section{Customer questionnaire}

The two part questionnaire developed to test customer perceptions and expectations of the service quality of telephonists, assessed service quality along each of the five dimensions, namely tangibles, reliability, responsiveness, assurance and empathy. It represented a modification of the SERVQUAL questionnaire, which has been tested for reliability and validity. Agreement or disagreement with the statements to test the expectations and perceptions of the service, were tested using a seven-point scale. Roughly half of the statements were worded positively, and the other half were worded negatively.

\section{Manager and telephonist questionnaire}

This questionnaire was designed using some of the specific variables related to establishing the service management gap for telephonists (Zeithaml et al., 1988). Some of the values derived during the focus group discussion were also incorporated. The telephonist questionnaire therefore included questions designed to measure teamwork, job fit, supervisory control, role conflict, role ambiguity and horizontal communication. The manager questionnaire measured market research orientation, upward communication, management commitment to service and the extent to which managers believed that customer expectations were being met. The results of these questionnaires were therefore used to assist in interpreting possible reasons for the existence or nonexistence of Gap 5. During the focus groups, it was suggested that with the advent of more sophisticated technology, the telephonists' job is gradually changing to that of an information or communications officer. The additional questions in the questionnaire related to this view.

The questionnaires were piloted with a small group of respondents to check for errors in ambiguity or comprehension and to determine time required for completion. The two part questionnaires were then delivered or faxed to customers together with a covering letter. The data from the telephonists and managers was obtained through semi structured interviews using the questionnaires.

\section{Discussion of research results}

\section{Analysis of the data}

The data from the telephonists and managers was analyzed qualitatively with a view to providing insight into the possible existence or non-existence of Gap 5. Customer expectation scores, as measured on the seven-point scale, indicated the perception about the service company in question.

The differences between perception and expectation scores represent the service quality scores. Possible values ranged from -6 to +6 . A mean and standard deviation were calculated for each of the five dimensions of customer expectations and customer perceptions scores for the four companies concerned. The quality scores along the five dimensions for each company were defined as being the difference between the expectation and perception score for each dimension. Non-responses in either expectations or perceptions resulted in the exclusion of the pair from the calculation of the quality score for the particular dimension tested. An average quality score was computed for the five dimensions for each company by calculating a numerical average of the quality scores.

\section{Statistical analysis}

Expectations and perceptions were obtained from respondents by asking them to express their agreement or disagreement with the statements on a seven-point ordinal scale. The assumption of a normal distribution could not be made and so a non-parametric test method was required, and the Mann-Whitney Two Sample (non-matched) test was used to evaluate whether the perceptions differed significantly from the expectations.

The results from the individual tests were reflected in the scores for the various firms as the probability that the perception did not differ significantly from the expectation. Confidence levels were set to $5 \%$ for two-sided tests, which meant that if the reported probability exceeded $2.5 \%$, the hypothesis that the perception was not significantly different from the expectation would be accepted.

\section{Expectations questionnaire}

A $100 \%$ response rate was obtained on the expectations questionnaire with the average expectation score being relatively high. This confirmed the generally held view that customer expectations tend to be high (Peters, 1987). Customer expectations were highest on the reliability dimension, followed by responsiveness, assurance, tangibles and empathy. This suggested that customers have high expectations of the telephonists' ability to perform their duties accurately and to be helpful and prompt, followed closely by the ability of telephonists to be knowledgeable and courteous.

A comparison between the overall expectations in this research and those of a long distance telephone company in the USA, along with the five SERVQUAL dimensions, are indicated in Table 1.

It can be seen that there is a similarity between the two in respect of the high expectations of reliability, as well as a close similarity along the other four dimensions. This consistency in customer expectations raises an interesting question for future research, namely, whether customer expectations along various facets of service companies are independent of the business sector to which they belong.

Table 1 Expectations on five SERVQUAL dimensions

\begin{tabular}{lcc}
\hline & $\begin{array}{c}\text { USA } \\
\text { Long-distance } \\
\text { telephone company }\end{array}$ & $\begin{array}{c}\text { South Africa } \\
\text { Service firm } \\
\text { telephonist }\end{array}$ \\
\hline Dimension & & \\
\hline Reliability & 6.79 & 6.40 \\
Responsiveness & 5.92 & 6.00 \\
Assurance & 6.55 & 5.83 \\
Tangibles & 5.79 & 5.58 \\
Empathy & 5.60 & 5.05 \\
\hline
\end{tabular}




\section{Telephonist questionnaire}

The responses to these questionnaires, which were done on a qualitative basis, indicated the existence of a gap between service quality specifications and service quality actually delivered, namely, the service performance gap (Gap 3). Zeithaml et al. (1988) cite teamwork, extent of employee and technology job fit, supervisory control systems, role conflict and role ambiguity as factors which contribute to the size and direction of this gap in service quality.

The results indicated that most telephonists felt left out and isolated from everyone else and that they did not get enough support from management and other employees. The implications for companies who want to build a culture for service quality, are to establish specific quality standards, recruit personnel with the capacity to meet these standards and train them to meet these standards. The results also reflect an absence of standardized selection techniques, such as personality tests, and very litue communication skills training. This tends to confirm research findings that customer contact jobs tend to be among the lowest paid, and the staff in these functions among the least educated (Zeithaml et al., 1988). More training in communications and more co-operation and acknowledgement from staff, particularly in view of the changing and more sophisticated role which they are expected to play, is perceived by telephonists to be important to them.

\section{Manager questionnaire}

The management questionnaire addressed the factors influencing Gaps 1 and 2. It was found that three of the four companies did market research but the research did not cover the service quality of the telephonist's service, although all the managers felt that it was important to establish what customers thought of the service. According to Zeithaml et al. (1988), a key to understanding consumer expectations and perceptions is through doing market research which focusses on the service quality, and implementing the results.

The results of this research indicated a lack of reward for and measurement of service quality. Companies that have been successful in delivering high quality service are noted for establishing formal goals relating to service quality and for monitoring the attainment thereof (Peters, 1987). Effective communication processes and more market research would maintain service delivery standards in line with the expectations of the customers. Although management acknowledges the important role played by the telephonist to the overall quality of the organization, they have not implemented communication and control processes to manage the service.

\section{Customer perceptions questionnaire}

These are discussed individually for each of the four organizations (see Table 2).

\section{Car hire firm}

The overall quality score was -1.57 , indicating that customer perceptions fell short of expectations overall. As indicated in Table 2, the car hire firm performed well along the determinants of empathy and tangibles and there was no
Table 2 Customer perceptions of the telephonist service of the car hire firm

\begin{tabular}{lccccc}
\hline & & & Quality & Std. \\
& Expectation & Perception & score & dev. & Probability \\
\hline Reliability & 6.40 & 3.50 & -2.90 & 2.26 & $0.00 \%$ \\
Responsiveness & 6.00 & 3.98 & -2.02 & 2.42 & $0.00 \%$ \\
Assurance & 5.83 & 3.78 & -2.05 & 2.46 & $0.00 \%$ \\
Tangibles & 5.58 & 5.39 & -0.19 & 1.66 & $55.56 \%$ \\
Empathy & 5.05 & 4.30 & -0.75 & 2.09 & $10.19 \%$ \\
\hline
\end{tabular}

significant difference between expectations and perceptions for these two determinants. However, since these are not the determinants on which customers have high expectations, it appears that their management is not focussing on the important expectations of their customers, namely those of reliability, which has the highest expectation and the highest gap, and responsiveness, where the gap is also more than two. This could be accounted for by a lack of market research, as confirmed by the results of the management and telephonists' survey, and tends to confirm the Parasuraman et. al. (1985) theory that the size and direction of Gap 5 will be affected by the degree of market research orientation and upward communication.

Telephonists felt that they were not getting the support from management and staff, and felt isolated and left out of the mainstream of the company's activities. However they did not feel any role conflict, and felt that management were caring and concerned. The training they received was mostly technical, which reflected on their perceived level of competence and their confidence.

\section{Courier service}

The average quality score across all the determinants was -0.97 . As demonstrated in Table 3 , the courier service greatly exceeded customers' expectations on the tangibles dimension, however the score on the assurance dimension could be considered a borderline case.

Once again there are significantly low scores on the dimensions of responsiveness and reliability, the two most important dimensions. Since this company advertise their services as responsible and reliable, this result implies that management is not in touch with, nor is it focusing on, customer needs and expectations.

The analysis of the responses from the managers and telephonists revealed a high degree of market research, except

Table 3 Customer perceptions of the telephonist service of the courier service

\begin{tabular}{lccccc}
\hline & Expectation & Perception & $\begin{array}{c}\text { Quality } \\
\text { score }\end{array}$ & $\begin{array}{l}\text { Std. } \\
\text { dev. }\end{array}$ & Probability \\
\hline Reliability & 6.40 & 4.52 & -1.88 & 1.94 & $-0.27 \%$ \\
Responsiveness & 6.00 & 4.15 & -1.85 & 1.64 & $0.00 \%$ \\
Assurance & 5.83 & 5.24 & -0.59 & 1.83 & $1.89 \%$ \\
Tangibles & 5.58 & 5.89 & -0.31 & 1.66 & $41.80 \%$ \\
Empathy & 5.05 & 4.12 & -0.93 & 1.59 & $1.17 \%$ \\
\hline
\end{tabular}


for the telephonists' function; technical training, except for communications and customer skills training; a lack of support in order to do their jobs; telephonists rated the degree of knowledge required about the company's services as not very important.

These results appear to confirm a discrepancy between the specification for the service and the actual delivery of the service. This may be due to the factors discussed as well as the lack of horizontal communication to the telephonist. The results for the perceptions of responsiveness and reliability tend to confirm that media advertising and other communications in the form of unfulfilled promises can affect customer expectations. The results tend to indicate the existence of Gaps 3 and 4, which influences the size of Gap 5.

\section{Hotel}

The outcome for the telephonist service for the hotel included in the study is contained in Table 4. The overall quality score for the telephonists in this organization was -0.62 , which was the highest of the four firms tested. Two noteworthy points which appear from the above, are that the perceptions of tangibles exceeded its expectation, and the perception of assurance almost equalled its expectation. The perception of reliability is also not significantly less than expected. However, the perception of empathy and responsiveness are both considerably less than expected.

Table 4 Customer perceptions of the hotel telephonist service

\begin{tabular}{lccrrr}
\hline & & \multicolumn{5}{c}{ Quality } & \multicolumn{1}{c}{ Std. } \\
& Expectation & Perception & score & dev. & Probability \\
\hline Reliability & 6.40 & 5.39 & -1.01 & 1.33 & $2.84 \%$ \\
Responsiveness & 6.00 & 4.60 & -1.40 & 2.18 & $0.00 \%$ \\
Assurance & 5.83 & 5.23 & -0.60 & 1.69 & $2.92 \%$ \\
Tangibles & 5.58 & 5.82 & 0.24 & 1.19 & $66.66 \%$ \\
Empathy & 5.05 & 3.92 & -1.13 & 1.67 & $1.13 \%$ \\
\hline
\end{tabular}

The market research which was performed on the hotel includes the service quality of the telephonist, and customer feedback is received on an ongoing basis in their 'Sixty second customer service critique'. This input is used for training and measuring service gaps, and the telephonists receive training on service as well as communications and customer care skills. The results of this approach are evidenced in the results of this research.

\section{Audit firm}

The average quality score of this firm was -1.30 . Noteworthy points from the results contained in Table 5 were as follows: the audit firm had the highest perception on the most important determinant, that of reliability; the perceptions as measured by the scores were significantly less than the expectations on all other determinants, which placed the audit firm third out of the four firms in this research survey; the order of the scores on the five determinants matched those of the expectations very closely, but this may be due to coincidence rather than to management
Table 5 Customer perceptions of the audit firm telephonist service

\begin{tabular}{lccccc}
\hline & & \multicolumn{5}{c}{ Quality } & Sud. \\
& Expectation & Perception & score & dev. & Probability \\
\hline Reliability & 6.40 & 5.50 & -0.99 & 1.40 & $4.42 \%$ \\
Responsiveness & 6.00 & 3.55 & -2.45 & 1.84 & $0.00 \%$ \\
Assurance & 5.83 & 4.75 & -1.08 & 1.55 & $0.01 \%$ \\
Tangibles & 5.58 & 4.92 & -0.66 & 1.34 & $1.02 \%$ \\
Empathy & 5.05 & 3.62 & -1.43 & 1.32 & $0.07 \%$ \\
\hline
\end{tabular}

actively addressing customer expectations. This is evidenced by the low quality score and the responses from telephonists and management; the relatively low standard deviations obtained on the scores indicate that opinions were shared between all customers. The responses from managers and telephonists reveal a very low market orientation, and although market research is done, this does not include the telephonist; no evidence of management commitment to service quality in the form of specific and measurable quality standards; there appears to be a difference in customer expectations and management perceptions of customer expectations, evidenced by the low score on responsiveness (for example, keeping the customer informed whilst on hold, was considered important for customers but not for management); the assurance dimension can be interpreted in relation to the training provided for telephonists - no customer relations training is provided.

\section{Combined scores of all firms tested}

When all the scores obtained on perceptions are combined and measured against expectations (Table 6) it appears that perceptions equal expectations only on the tangibles aspect. The physical appearance is the easiest determinant to manage and measure, which is why most firms scored well on that determinant. The low scores show that even well-known firms such as the four involved in this study have room for improving their in-house telephone service quality.

The two determinants most important to customers are reliability and responsiveness. In other words, customers have high expectations of a company's ability to perform the promised service dependably, their willingness to help customers and their ability to provide a prompt service.

In Figure 1 is illustrated the distributions of the combined quality scores of the four organizations tested. The distribution of the combined scores indicates that, on average, the

Table 6 Combined scores for all firms tested

\begin{tabular}{|c|c|c|c|c|c|}
\hline & Expectation & Perception & $\begin{array}{l}\text { Quality } \\
\text { score }\end{array}$ & $\begin{array}{l}\text { Std. } \\
\text { dev. }\end{array}$ & Probability \\
\hline Reliability & 6.40 & 3.97 & -2.43 & 2.43 & $0.00 \%$ \\
\hline Responsiveness & 6.00 & 3.93 & -2.07 & 2.15 & $0.00 \%$ \\
\hline Assurance & 5.83 & 4.43 & -1.40 & 2.25 & $0.00 \%$ \\
\hline Tangibles & 5.58 & 5.21 & -0.37 & 1.87 & $23.22 \%$ \\
\hline Empathy & 5.05 & 3.72 & -1.33 & 1.97 & $0.02 \%$ \\
\hline
\end{tabular}




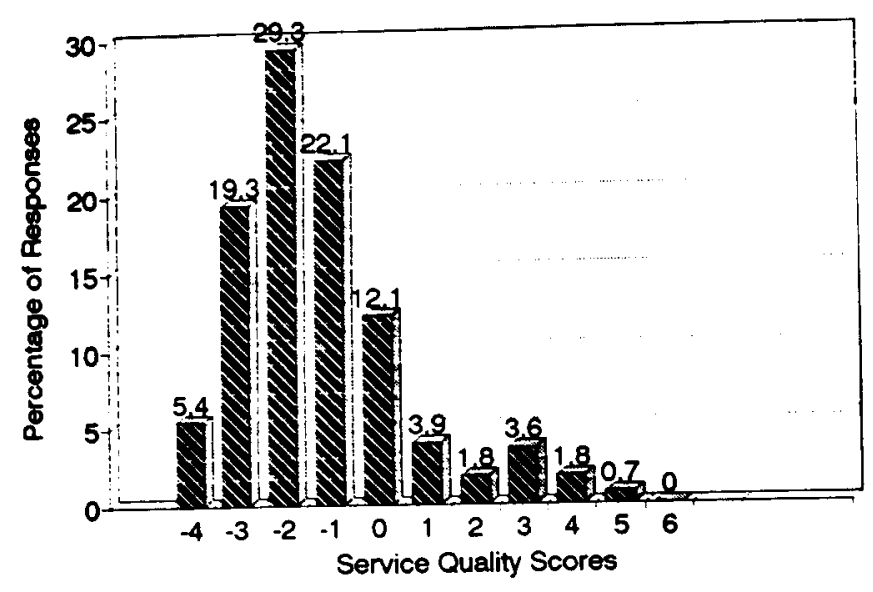

Figure 1 Combined service quality scores

perception of the received service is well below the expectations.

\section{Conclusions and recommendations}

This research set out to test whether a gap existed between customers' expectations of the service quality of telephonists and their perceptions. The conclusion is made that, although in some instances expectations were equalled or exceeded, in general perceptions did not match expectations.

The dimensions along which service quality is most lacking are reliability and responsiveness. Investigations may prove that failing to inform the telephonist about staff whereabouts results in the telephonist putting calls through to the wrong department or person, or that the call is routed to various departments. Implementation of effective communication and control processes would enhance the performance along the reliability and responsiveness dimensions.

The SERVQUAL scale could be used to test customer perceptions on an aspect of the service. The benefits of using this scale are that it has diagnostic value, such as the fact that one is able to determine where the discrepancy comes from, whether this be from high or low perceptions or both. Identification of low service areas within the company may uncover key factors that facilitate or hinder the delivery of high quality service. For example, if expectations on empathy are believed to be reasonable, but perceptions are poor, a suitable training programme for customer contact personnel may be called for.

There is also great value in combining the SERVQUAL scale with the conceptual model of service quality. Despite the small sample, this research highlighted some very definite patterns by using this approach, and confirmed the factors indicated by Zeithaml et al. (1988) as indicators of the existence and direction of gaps in the service quality provided.

A service firm's customers can be segmented into several perceived quality groups, such as high, medium and low, on the basis of their individual service quality scores. Identification of the distinguishing characteristics of each customer segment may provide the firm with valuable insights for its marketing and promotional strategies.

The service organizations tested generally appear not to differentiate themselves successfully, companies should begin to see the in-house telephone system as an extension of the company's service, and, as with all other services provided, should begin to monitor and manage it.

If an organization wants its employees to give their customers high quality treatment, then the organization has to give its employees high quality treatment. The core issue for organizations desirous of service excellence, is to communicate that everyone is part of a team and the success of the organization depends on the performance of everyone involved.

Future researchers may wish to investigate the correlation between the service quality of telephonists, as established in this research, with the overall service quality of the firm. Further research could also investigate whether the rank order of expectations are indicative of the importance placed on dimensions in evaluating service quality. Finally, the validity of the SERVQUAL questionnaire in the South African context may prove to be another interesting direction for future researchers to follow.

\section{References}

Albrecht, K. \& Zemke, A. 1985. 'Instilling a service mentality: Like teaching an elephant to dance.' International Management, November.

De Sola Pool, I. (ed.) 1977. The social impact of the telephone. Cambridge, Massachusetts: MIT Press.

George, W. \& Berry, L. 1981. 'Guidelines for the advertising of services'. Business Horizons, July-August.

Gronroos, C. 1982. Strategic managemns and marketing in the service sector. Helsingfors: Swedish School of Economis and Business Administration, Research Report No. 8.

Holbrook, M.B. \& Corfman, K.P. 1985. 'Quality and value in the consumption experience: Phaedrus rides again'. In: Jacoby, J. \& Olson, J. (eds.). Perceived quality. Lexington, MA: Lexington Books.

Jacoby, J.and Olson, J. (eds.). 1985. Perceived quality. Lexington, MA: Lexington Books.

Keller, S. 1977. 'The telephone in new (and old) communities'. In: De Sola Pool, I. (ed.). The social impact of the telephone. Cambridge, Massachusettes: MIT Press.

Levith, T. 1976. 'Industrialization of service'. Harvard Business Review, Vol. 54, No 5.

Lovelock, C.H. 1981. 'Towards a classification of services'. In: Berry, H.L., Shostach, G.L. \& Upah, G. (eds.). Emerging per spectives on services marketing. Chicago: American Marketing Association.

Lovelock, C.H. 1984. 'Managing the service marketing system'. Services Marketing. Englewood Cliffs, New Jersey: Prentice Hall.

Maister, D.H. 1985. 'The psycology of waiting lines'. In: Ezpiel, S. \& Supernant, ? (eds.). The service encounter. New York: Lexington Press.

Oliver, R. 1981. 'Measurement and evaluation of satisfaction process in retail settings'. Journal of Retailing, Vol. 57, No. 3.

Olsavsky, R.W. 1985. 'Perceived quality in consumer decision making: An integrated theoretical perspective'. In: Jacoby, J. \& Olson, J. (eds.). Perceived quality. Lexington, MA: Lexington Books, pp.3-29.

Parasuraman, A. \& Zeithaml, V.A. 1983. 'Differential perceptions of suppliers and clients of industrial services'. In: Berry, 
L., Shostach, G.L. \& Upah, G. (eds.). Emerging perspectives on services marketing. Chicago: American Marketing Association.

Parasuraman, A., Zeithaml, V.A. \& Berry, L.L. 1986. SERVQUAL: A multiple item scale for measuring customer perceptions of service quality. Report No. 86-108. CA. Massachussettes: Marketing Science Institute.

Parasuraman, A. \& Zeithaml, V.A. 1985. 'A conceptual model of service quality and its implications for future research'. Journal of Marketing, Vol. 49.

Parasuraman, A., Zeithaml, V.A. \& Berry, L.L. 1988. 'SER: VQUAL: A multi-item scale for measuring consumer perceptions of service quality'. Journal of Retailing, Vol. 64, No. 1: 41-50.

Peters, T. 1987. Thriving of chaos: Handbook for a management revolution. New York: A. Korfman Inc.
Sasser, W.E., Olsen, R.P. \& Wyckoff, D.D. 1978. Management of service operations: Texts and cases. Boston: Allyn and Bacon.

Thompson, P., De Souza, G. \& Gale, B.T. 1985. 'The strategic management of service quality. Pimsletter. No. 33. Cambridge, MA: The Strategic Planning Institute.

Zeithaml, V.A., Parasuraman, A. \& Berry, L.L. 1985. 'Problems and strategies in service marketing'. Journal of Marketing, Vol. 49: 41-50.

Zeithaml, V.A. 1986. Defining a price, perceived quality and perceived value. Working Paper, Durham, North Carolina: Duke University.

Zeithaml, V.A., Parasuraman, A. \& Berry, L.L. 1988. 'Communication and control processes in the delivery of service quality'. Journal of Marketing, Vol. 52: 35-48. 